\title{
One Step Towards: The Synthesis of Optimized Coumarin Derivatives as an Anti-HIV Agent
}

\author{
Vikas Kumar ${ }^{1, \star}$, Indra Prashad Pandey ${ }^{1}$, Jainendra Jain², Ram Babu Tripathi ${ }^{2}$ \\ ${ }^{1}$ Research Scholar of Uttarakhand Technical University, Department of Chemistry, Uttarakhand, INDIA. \\ ${ }^{2}$ Ram-Eesh Institute of Vocational and Technical Education, Noida, Uttar Pradesh, INDIA.
}

\begin{abstract}
The development for the sustainable approach was a key ingredient for the research, especially in the field of drug development against HIV. Several attempts have been made in the positive direction for the treatment of fatal disease, however the suitable lead was missing in the therapeutically arena. Many different kinds of natural products, including coumarins, have been found to be active in the various anti-HIV models and still investigation is undergoing. The present finding demonstrates the synthesis of the best fit compound, which was revealed in the previously published research. The insilico study is further justified with the synthetic approach and their characterization. The in-silico based optimized coumarin structure have been tried to get closer to the drug discovery process, where in the future it will be evaluated for the in-vitro / in-vivo biological screening to get the lead molecule for the treatment of HIV. The objective of this research is to evaluate data on coumarins' potent activity with respect to the inhibition of HIV-reverse transcriptase; Structural modification is a powerful tool to increase the potential of bioactive principles. By applying scientific expertise and modern scientific technology, new single compounds will assuredly be developed as potent antiHIV candidates for world-class new drug development.
\end{abstract}

Key words: Coumarins, HIV integrase inhibitors, Protease inhibitors, Reverse transcriptase inhibitors, QSAR.

\section{INTRODUCTION}

(HIV) Human Immunodeficiency Virus induces disease in humans that is known as AIDS (acquired immunodeficiency syndrome). ${ }^{1}$ Principal AIDS cases were registered in 1981 when the Centers for Ailment Management (CDC) has identified a bunch of pneumocystis carinii group of five gay men in Los Angeles In 1982, the authority given the name of AIDS to this disease. ${ }^{2}$ There are now two sort of HIV infection, HIV 1 and HIV 2 as infects, which was reported by Luc Montagnier in 1983 and 1986. HIV 1 disease had come from Congo in 1959 and 1960. ${ }^{3}$ While HIV-2 could be produced from mostly geographical pitchy catarrhine (Atys from Cercocebus). ${ }^{4}$

In comparison with HIV-2, HIV-1 is extreme virulent and the most commonly found globally in HIV medicines. ${ }^{5}$ At the stage of development of $\mathrm{HIV}$ is triggered when host cells, particularly immune system cells, are associated with $\mathrm{T}$ lymphocytes, macrophages and cells of nerve fiber. ${ }^{6}$ It has led to a reduction of CD4 $+\mathrm{T}$ cell levels through three primary processes: immediate bacterial killing of infected cells, a boost in cell mortality in affected cells and the killing by CD8 of tainted CD4 + T neurons that can identify cells produced by the viruses. CD4 + T tissues are damaged and can cause damage to the immune system's function and deficiency. Normal CD4+T concentrations are sometimes between 800 and one, 200 cells $/ \mathrm{mm}^{3}$ in safe uninfected populations. ${ }^{7}$ The advance of HIV disease lowers the amount of CD4 + T neurons and once below $200 / \mathrm{mm}^{3}$, people become considerably exposed to the diseases and opportu-
Submission Date: 28-06-2019; Revision Date: 03-08-2019; Accepted Date: 26-09-2019

DOI: 10.5530/ijper.53.4s.158 Correspondence: Mr. Vikas Kumar, Research Scholar of Uttarakhand Technical University, Department of Chemistry, Uttarakhand, INDIA. Phone: +91 8894001645 E-mail: vikasnagaich@gmail. com

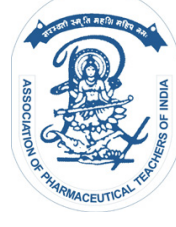

www.ijper.org 
nistic infections of micro-organisms (such as neoplastic disease and lymphomas of Kaposi), typically without infecting people with an adaptive mechanism. Opportunistic diseases (OIs) are therefore more prevalent and more serious diseases among folks who have reduced defense system (immunity). ${ }^{8}$

The HIV epidemics impact not only people's safety, but also societies, economic growth and nation-building. At the beginning of 2016, there were around 36.7 million global HIV / AIDS sufferers. In June 2017, an Antiretroviral Treatment (ART) was used by 20.9 million individuals residing with HIV. ${ }^{9}$ India's HIV epidemic is the world's third biggest. An approximately $0.2 \%$ of adult HIV incidence (15-49 years old) was in 2017. This number is low in comparison with most other nations with middle income, but due to the enormous inhabitants of India (1.3 billion persons); 2.1 million individuals live with HIV. The visual transfer drives the HIV outbreak in India and represented $86 \%$ of the fresh diseases between 2017 and 2018. ${ }^{10}$ The three states with the greatest HIV in the nation are Manipur, Mizoram and Nagaland. However, the vulnerabilities which cause the epidemic in various places in the nation differ. ${ }^{11}$ The epidemic is focused among main impacted communities. Unprotected gender is a main factor between important people and their customers, associates and spouses. However, the incidence of HIV is also increasing with the use of injection, drugs in the north. ${ }^{12}$ (Figure 1)

\section{Background of Research}

Therefore, various methods have been developed for the total synthesis of coumarins, ${ }^{13}$ including the Perkin, Pechmann and Knoevenagel reactions. In this experiment 83 ligands (Calanolide derivative) were obtained from NIH data base and molecular docking interactions were studies with non- nucleoside reverse transcriptase HIV-1 virus (3HVT, IKW, 1LW2), complexes with standard inhibitor of nevirapine and Efavirenz. Interactions were studied in terms of $\mathrm{H}$-bonding and pi stacking. All these compounds have displayed hydrogen bond interactions with Tyr-181A, Lys-103A, Glu-130B, Lys$101 \mathrm{~A}$ and Leu- 422A residues. The initial interactions has been covered in the Figure 2 , which is the clear picture to rationalized the activity inside the active site of enzyme, which was reason to synthesize the compounds for the further identification of the lead. ${ }^{14}$

When searched out to most potent molecules with the help of docking results, it was found that a bicyclic ring of coumarins attached with a substituent benzofuranone involved in hydrogen bond interactions. So that on the basis of docking results a calanolides derivatives with coumarin nucleus were designed in a such way that it forms hydrogen bonding with reverse transcriptase enzyme.

In the previous study of our lab was carried out with many calanolides derivatives, out of, many, compounds like (7a, 7b and 7c) have displayed strong H-bonding interactions with $\mathrm{IC}_{50}$ from $3 \mathrm{HVT}$, IKW, 1LW2 macromolecules respectively (Figure 3 ) indicating potent inhibition of HIV-1 virus. One of the Compounds was found most potent analogs displaying H-Bonding of $1.804 \AA$. This value was found to be in accordance with the corresponding $\mathrm{IC}_{50}$ values of $0.161 \mu \mathrm{M}$ indicating a direct correlation between H-bond value and HIV-1 inhibition. All these compounds have displayed interactions with Tyr-181A, Lys-103A, Glu-130B, Lys-101A and Leu-422A residues. The structural component of various calanolide derivatives involved in $\mathrm{H}$-bonding indicating the active involvement of these oxygen atoms in $\mathrm{H}$-bonding. Coumarins nucleus with benzo-furan ring (compound 011954) was observed as the most potent analogues from the series. This was also supported by strong $\mathrm{H}$-bond value, indicating that bicyclic coumaring ring system with benzo-furan moiety as the lead compounds from the series. Benzyl furan and triazidine with aliphatic side chain have shown comparatively less strong $\mathrm{H}$-bonding interactions with $3 \mathrm{HVT}$. This was also supported by their greater $\mathrm{IC}_{50}$ values. ${ }^{14}$

\section{Synthesis of Compounds (7a-7c)}

The molecules which were found most promising after QSAR and molecular docking studies were synthesized by the following series. The purity of compounds was checked by single-spot TLC using $\mathrm{n}$-Hexane: acetone (9:1), n-Hexane: Chloroform: ethyl methyl ketone (7:1.5:1.5) and n Hexane: Chloroform: Methanol (4:3:3) solvent systems and spots located under iodine vapors/ UV light. The structures of the synthesized compounds were established on the basis of modern analytical techniques; IR and NMR. Herein, we report the highly efficient total synthesis of three $(7 \mathrm{a}, 7 \mathrm{~b}$ and $7 \mathrm{c}$ ) novel 3-acetyl-6 amino coumarin derivatives. ${ }^{15-17}$

The molecule, found most promising after molecular docking and QSAR studies was synthesized by following multiple steps. The starting material (4) was synthesized from the Benzopyran derivative (1), which was subjected for Nitration reaction (2), The nitration of the aromatic takes place through the strong $\mathrm{El}\left(\mathrm{NO}_{2}+\right)$ by the reaction of sulfuric acid and nitric acid. The sulfuric acid protonates the nitric acid, which results in the formation of cationic El. The cationic El proceeds to the substitution of the aromatic ring. (Figure 4) 
The nitration compound was subjected for the esterification product (3) and in the final step for the intermediate (4) was perform by the reduction of nitro group to the amine.

The intermediate (4) was used for the synthesis of the potent molecule which is described in the scheme 2 with the various ways.

\section{Synthesis and characterization of Promising Active Molecules (7a-7c) ${ }^{18,19}$}

Based on the instrumental analysis these compounds were identified through NMR and IR spectroscopy. The data of each compound is given in the number context with the front of each compound.

\section{a) Synthesis of 6-acetamido-2-oxo-2H-1- benzopyran-3-carboxylic acid (7a)}

The previously synthesized molecule of methyl-6-acetamido-2-oxo-2H-1-benzopyran-3-carboxylate $(0.190 \mathrm{~g}, 0.72 \mathrm{mmol})$ was used as a starting material, which was mixed with water $(1.5 \mathrm{ml})$, Methanol (1.5 $\mathrm{ml})$ and THF $(1.5 \mathrm{ml})$, then further $\mathrm{LiOH}$ monohydrate $(2.16 \mathrm{mmol})$ were added and RM was stirred at RT for $6 \mathrm{hr}$. when all starting materials were consumed reaction mass was acidified with $3 \mathrm{M} \mathrm{HCl}$ solution until $2.0 \mathrm{pH}$ was reached and extracted with ethyl acetate. Organic layer was dried over sodium sulfate and distilled out under vacuum to get crude product. A crude product was recrystallized with diethyl ether and gets 6-acetamido-2-oxo-2H-1-benzopyran-3-carboxylic acid (7a) (0.098 g, yield- 54.74\%) LCMS-245.96

\section{${ }^{1} \mathrm{H}-\mathrm{NMR}-(\mathrm{DMSO}, 400 \mathrm{MHz})$}

As presented in Figure 5

$\delta \mathrm{ppm}=13.22\left(\mathrm{br} \mathrm{s}, 1 \mathrm{H}, \mathrm{OH}, \mathrm{H}_{24}\right), 10.21(\mathrm{~s}, 1 \mathrm{H}, \mathrm{NH}$, $\left.\mathrm{H}_{11}\right), 8.69\left(\mathrm{~s}, 1 \mathrm{H}, \mathrm{ArH}, \mathrm{H}_{17}\right), 8.10\left(\mathrm{~s}, 1 \mathrm{H}, \mathrm{ArH}, \mathrm{H}_{15}\right), 7.99$ $7.44\left(\mathrm{~d}, 2 \mathrm{H}, \mathrm{ArH}, \mathrm{H}_{14}, \mathrm{H}_{18}\right)$

\section{IR spectrum (KBr) (Figure 6)}

3370(Amide-NH str), 3076(Aromatic-CH str), 2601(Carboxylic acid-OH str), 1737(Lactone ester), 1645(Amide-CO), 1557 ( $\mathrm{C}=\mathrm{C}$ aromatic).

\section{b) Synthesis of 6-benzamido-2-oxo-2H-1-}

benzopyran-3-carboxylic acid (7b)

The previously synthesized molecule of methyl 6-benzamido-2-oxo-2H-1-benzopyran-3-carboxylate $(0.40 \mathrm{~g}, 1.23 \mathrm{mmol})$ was mixed with mixtures of water $(1.5 \mathrm{ml})$, Methanol $(1.5 \mathrm{ml})$ and THF $(1.5 \mathrm{ml})$ then added $\mathrm{LiOH}$ monohydrate $(3.69 \mathrm{mmol})$ and $\mathrm{RM}$ were stirred at RT for $6 \mathrm{hr}$. When all starting materials were consumed reaction, mass acidified with $3 \mathrm{M} \mathrm{HCl}$ solution until $2.0 \mathrm{pH}$ was reached and extracted with ethyl acetate. Organic layer was dried over sodium sulfate and distilled out under vacuum to get crude product. Crude product was recrystallized with diethyl ether and gets 6-benzamido-2-oxo-2H-1-benzopyran-3-carboxylic acid (7b) (0.110 g, yield- 28.79\%) LCMS-308.02 (-ve).

\section{IR spectrum ( $\mathrm{KBr})$}

3314(N-H str), 3056(aromatic C-H str), 2841(carboxylic acid $\mathrm{OH}$ str), 1744 (lactone ester), 1693 (C=O amide), 1537 (C=C aromatic), 1424 (C-O-C str),

\section{H-NMR- (DMSO, $400 \mathrm{MHz}$ )}

$\delta=13.25(\mathrm{~b}, 1 \mathrm{H}), 10.53(\mathrm{~s}, 1 \mathrm{H}), 8.72(\mathrm{~s}, 1 \mathrm{H}), 8.32(\mathrm{~s}, 1 \mathrm{H})$, $7.98(\mathrm{~d}, \mathrm{j}=6.88,3 \mathrm{H}), 7.60(\mathrm{~d}, \mathrm{j}=6.88,1 \mathrm{H}), 7.57-7.53(\mathrm{~m}$, $2 \mathrm{H}), 7.47(\mathrm{~d}, \mathrm{j}=8.72,1 \mathrm{H})$

Synthesis of 6-(4-chlorobenzamido)-2-oxo-2 H-1-benzopyran-3- carboxylic acids (7c)

The previously synthesized molecule of methyl 6-(4-chlorobenzamido)-2-oxo-2H-1-benzopyran-3-carboxylate (6c) $(0.390 \mathrm{~g}, 1.09 \mathrm{mmol})$ was mixed with mixtures of water $(1.5 \mathrm{ml})$, Methanol $(1.5 \mathrm{ml})$ and THF (1.5 $\mathrm{ml})$ then added $\mathrm{LiOH}$ monohydrate $(3.69 \mathrm{mmol})$ and RM were stirred at RT for $6 \mathrm{hr}$. When all starting materials were consumed reaction mass acidified with $3 \mathrm{M}$ $\mathrm{HCl}$ solution until $2.0 \mathrm{pH}$ was reached and extracted with ethyl acetate. Organic layer was dried over sodium sulfate and distilled out under vacuum to get crude product. Crude product was recrystallized with diethyl ether and get 6-(4-chlorobenzamido)-2-oxo-2H-1-benzopyran-3-carboxylic acid (7c) (0.120 g , yield- 32.08\%) LCMS-341.97(-ve)

\section{IR spectrum ( $\mathrm{KBr})$}

3391 (Amide-NH), 3055 (Aromatic-CH), 2596(Carboxylic acid-OH) 1760 (lactone ester), 1669 (Amide CO), 1618(Amide-NH), 1618 (Amide-NH), 1573 (Aromatic C-C), $800(\mathrm{C}-\mathrm{Cl})$

\section{NMR: 1H-NMR- (DMSO, $400 \mathrm{MHz}$ )}

$\delta \mathrm{ppm}=13.26\left(\mathrm{br} \mathrm{S}, 1 \mathrm{H}, \mathrm{OH}, \mathrm{H}_{24}\right), 10.59(\mathrm{~s}, 1 \mathrm{H}, \mathrm{NH}$, $\left.\mathrm{H}_{11}\right), 8.72\left(\mathrm{~s}, 1 \mathrm{H}, \mathrm{ArH}, \mathrm{H}_{17}\right), 8.30\left(\mathrm{~s}, 1 \mathrm{H}, \mathrm{ArH}, \mathrm{H}_{15}\right), 8.02-$ 7.96(m, 3H, ArH, $\left.\mathrm{H}_{6}, \mathrm{H}_{9}\right), 7.64-7.52$ (d, 2H, ArH, $\mathrm{H}_{14}$, $\mathrm{H}_{18}$ ),

The objective of the present study is to extend the study further to the in-silico to the synthesis. Many calanolides derivatives, out of, many, compounds like (7a, $7 \mathrm{~b}$ and $7 \mathrm{c}$ ) have displayed strong H-bonding interactions with 3HVT, IKW, 1LW2 macromolecules respectively indicating potent inhibition of HIV-1 virus. All these compounds had displayed interactions with Tyr-181A, Lys-103A, Glu-130B, Lys-101A and Leu-422A residues. The structural component of various calanolide derivatives involved in $\mathrm{H}$-bonding indicating the active involvement of these oxygen atoms in $\mathrm{H}$-bonding. This 


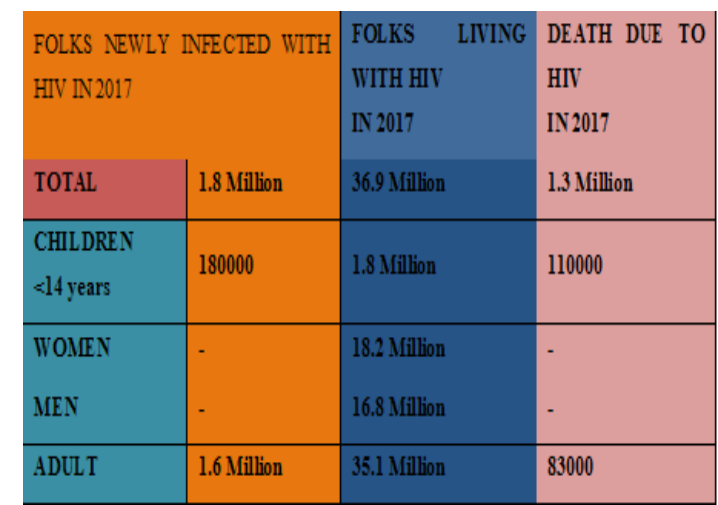

Figure 1: HIV epidemic global data of 2017 to 2019.

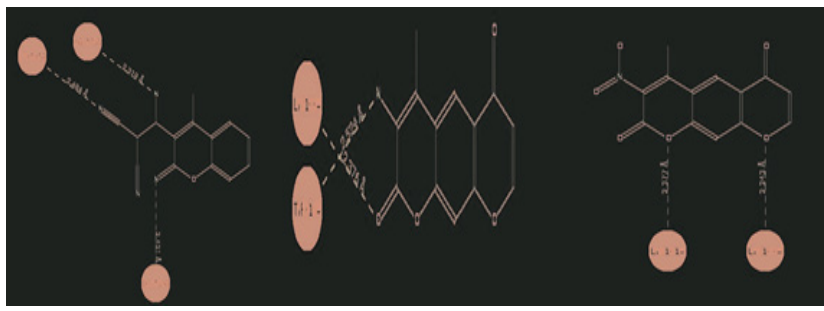

Figure 2: Interaction of Calanolide derivatives in the active site of enzyme.

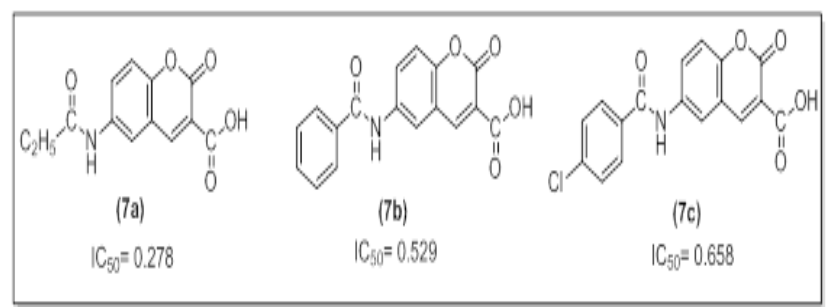

Figure 3: Active compounds from the series of calanolide derivatives.

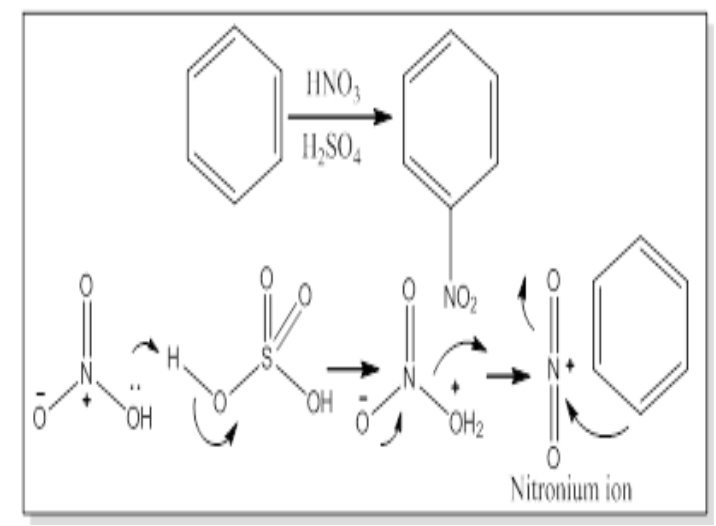

Figure 4: Nitration of Aromatic ring.

was also supported by their greater $\mathrm{IC}_{50}$ values as mentioned in the manuscript. In the present in-silico study has been extended to the synthesis, where the synthesized coumarin scaffold-based compounds 3-acetyl-coumarin derivatives, $(7 \mathrm{a}-7 \mathrm{c})$. Synthesis of the lead will open-up

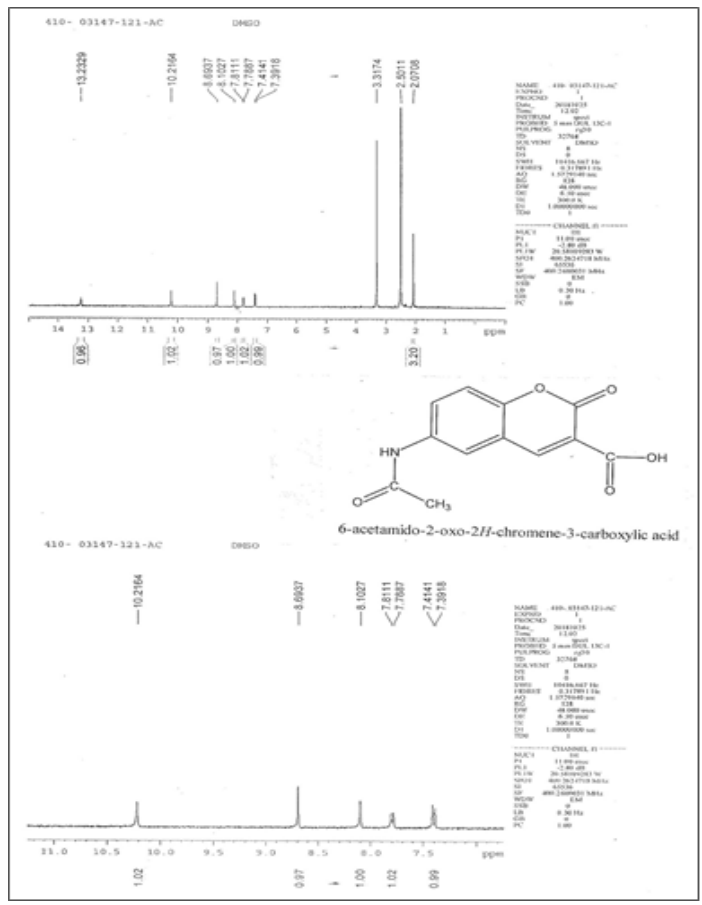

Figure 5: NMR spectra of compound (7a).

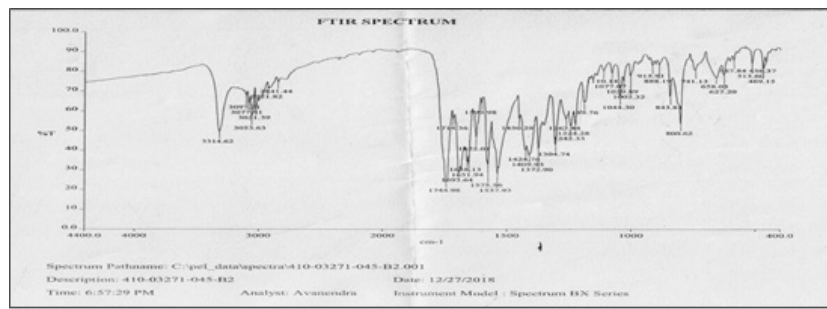

Figure 6: IR spectra of compound (7a).

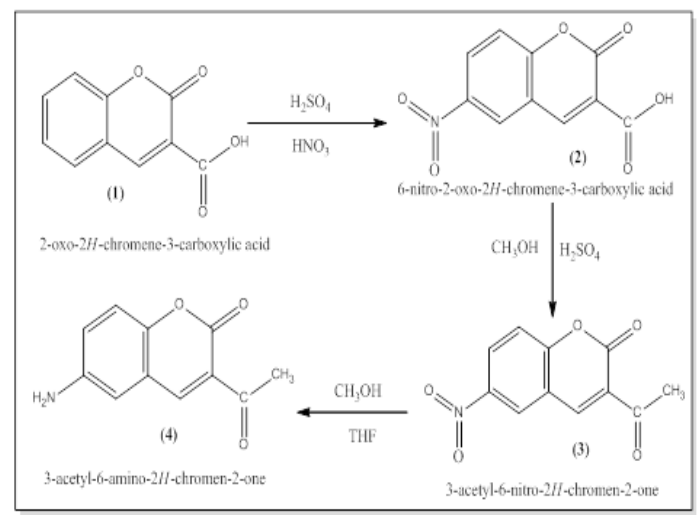

Scheme 1: Synthesis of Intermediate (4).

space for the in-vitro to clinical study, which may be a lead for the betterment of the HIV patients.

Based on the instrumental analysis these compounds were identified through NMR and IR instruments. The data of each compound is given in the number context 


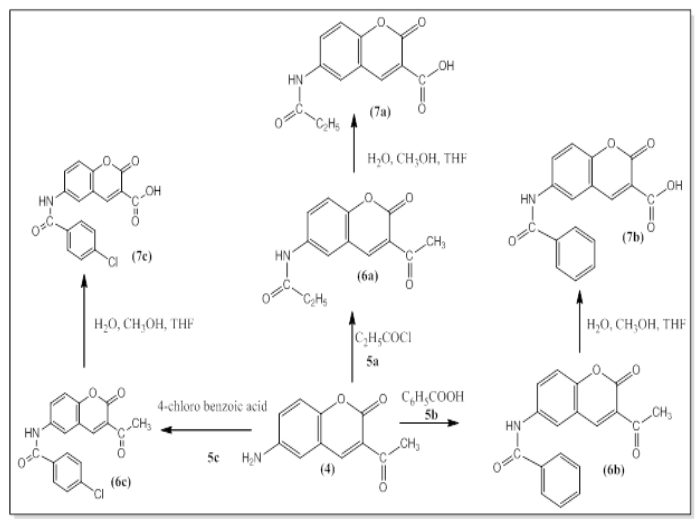

Scheme 2: Synthesis of active compounds (7a-7c).

with the front of each compound. The all compounds (7a- 7c) were synthesized and characterized for the further development of the anti-HIV lead.

\section{CONCLUSION}

The synthesized compounds will act as a lead and will serve the society against the vital disease. The initial in-silico finding of the compounds is a hint, which is further extended here and in near future it will be a successful lead.

\section{ACKNOWLEDGEMENT}

Technical support from Department of Pharmacy, Ram Eesh Institute of Vocational and Technical Education Greater Noida, UP is gratefully acknowledged.

\section{CONFLICT OF INTEREST}

The authors declare no conflict of interest.

\section{ABBREVIATIONS}

NMR: Nuclear magnetic resonance; IR: Infrared; THF: Tetrahydrofuran; RM: Reaction Mixture; LCMS: Liquid chromatography-mass spectrometry; RT: Room temperature; QSAR: Quantitative structure-activity relationship; TLC: Thin layer Chromatography; Tyr: Tyrosine; Lys: Lysine; Glu: Glutamic Acid; Lys: Lysine; Leu: Leucine; HIV: Human immunodeficiency virus; AIDS: Acquired immunodeficiency syndrome; CDC: Centers for Ailment Management; ART: Antiretroviral treatment.

\section{REFERENCES}

1. Coffin J, Haase A, Levy JA, Montagnier L, Oroszlan S, Teich N, et al. Human immunodeficiency viruses. Science. 1986;232(4751):697.

2. Kallings LO. The First Postmodern Pandemic: 25 Years of HIVIAIDS. Journal of Internal Medicine. 2008;263(3):218-43.

3. Clavel F, Guyader M, Guétard D, Sallé M, Montagnier L, Alizon M. Molecular cloning and polymorphism of the human immune deficiency virus type 2. Nature. 1986;324(6098):691.

4. UNAIDS Report on the Global AIDS Epidemic 2010, based on 2010 UNGASS Country Reports, UNAIDS / 11.05E ISBN 978-92-9173-9035. UNAIDS, WHO (December 2011). 2010. AIDS epidemic update. www. unaids.org

5. Ariën KK, Vanham G, Arts EJ. Is HIV-1 evolving to a less virulent form in humans?. Nature Reviews Microbiology. 2007;5(2):141.

6. Fauci AS. The human immunodeficiency virus: Infectivity and mechanisms of pathogenesis. Science. 1988;239(4840):617-22.

7. Levy JA. Pathogenesis of human immunodeficiency virus infection. Microbiology and Molecular Biology Reviews. 1993;57(1):183-289.

8. Brenchley JM, Hill BJ, Ambrozak DR, Price DA, Guenaga FJ, Casazza JP, et al. T-cell subsets that harbor Human Immunodeficiency Virus (HIV) in vivo: Implications for HIV pathogenesis. Journal of Virology. 2004;78(3):1160-8.

9. Smith MZ, Wightman F, Lewin SR. HIV reservoirs and strategies for eradication. Current HIVIAIDS Reports. 2012;9(1):5-15.

10. Patrikar S, Kachroo K, Sharma J, Kotwal A, Basannar DR, Bhatti VK, et al. A systematic review and cost-effectiveness analyses of the new World Health Organization guidelines for the treatment of HIV-positive adults in India. Medical Journal Armed Forces India. 2019;75(1):31-40.

11. Ramya I, Mitra S, D'Sa S, Sathyendra S, Zachariah A, Kumar CV, et al. Outcomes and factors influencing outcomes of critically ill HIV-positive patients in a tertiary care center in South India. Journal of Family Medicine and Primary Care. 2019;8(1):97.

12. Hemelaar J, Elangovan R, Yun J, Dickson-Tetteh L, Fleminger I, Kirtley S, et al. Global and regional molecular epidemiology of HIV-1, 1990-2015: A systematic review, global survey and trend analysis. The Lancet Infectious Diseases. 2019;19(2):143-55.

13. Kashman Y, Gustafson KR. HIV inhibitory natural products. Part 7. The calanolides, a novel HIV-inhibitory class of coumarin derivatives from the tropical rainforest tree, Calophyllum lanigerum. Journal of Medicinal Chemistry. 1992;35(15):2735-43.

14. Vikas K, Indra PP, Jainendra J. An insight to structural analysis of coumarins as non nucleoside reverse transcriptase inhibitors. Wjert. 2017;3(4):178-95.

15. Murray RDH, Mendez J, Brown S. A: The Natural Coumarins: Occurrance, Chemistry and Biochemistry, John Wiley and Sons, New York. 1982.

16. Maheswara M, Siddaiah V, Damu GLV, Rao YK. Green Synthesis of a Fluorescent Natural Product. Journal of Molecular Catalysis. 2006;255(12):49.

17. Bigi F, Chesini L, Maggi R, Sartori G. Montmorillonite KSF as an inorganic, water stable and reusable catalyst for the Knoevenagel synthesis of coumarin3-carboxylic acids. Journal of Organic Chemistry. 1999;64(3):1033-5.

18. Dittmer DC, Li Q, Avilov DVJ. Synthesis of coumarins, 4-hydroxycoumarins and 4-hydroxyquinolinones by tellurium-triggered cyclizations. Journal of Organic Chemistry. 2005;70(12):4682-6.

19. Das S, Majee A, Hajra A. A convenient synthesis of coumarins using reusable ionic liquid as catalyst. Green Chemistry Letters and Reviews. 2011;4(4):349-53. 


\section{PICTORIAL ABSTRACT}

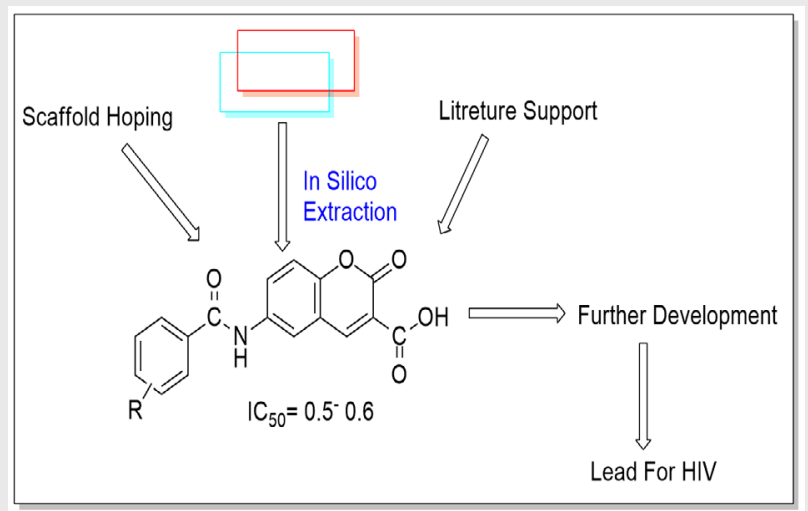

SUMMARY

The in-silico based optimized coumarin structure have been tried to get closer to the drug discovery process, where in the future it will be evaluated for the in-vitro / in-vivo biological screening to get the lead molecule for the treatment of HIV. The objective of this research is to evaluate data on coumarins' potent activity with respect to the inhibition of HIV-reverse transcriptase; Structural modification is a powerful tool to increase the potential of bioactive principles. By applying scientific expertise and modern scientific technology, new single compounds will assuredly be developed as potent anti HIV candidates for world-class new drug development

\section{About Author}

Vikas Kumar, M.Sc Analytical Chemistry, Pursuing Ph.D from Uttarakhand Technical University, Dehradun.

Cite this article: Kumar V, Pandey IP, Jain J, Tripathi RB. One Step Towards: The Synthesis of Optimized Coumarin Derivatives as an Anti-HIV Agent. Indian J of Pharmaceutical Education and Research. 2019;53(4s):s624-s629. 